\title{
EFFECT OF INSTITUTIONAL POLICY ON EMPLOYEE PERFORMANCE OF ACADEMIC STAFF OF PUBLIC UNIVERSITIES IN NIGERIA
}

\author{
Okolocha, Chizoba Bonaventure ${ }^{1}$ \\ Department of Entrepreneurship Studies \\ Nnamdi Azikiwe University, Awka \\ E-mail: cb.okolocha@unizik.edu.ng (corresponding author) \\ Okolocha, Chimezie Comfort ${ }^{2}$ \\ Department of Technology \& Vocational Education \\ Nnamdi Azikiwe University, Awka \\ Email: chimezie4gilbert@yahoo.com \\ Ezejiofor, Raymond Asika ${ }^{3}$ \\ Department of Accountancy, \\ Nnamdi Azikiwe University, Awka \\ Email: thaddray4life@yahoo.com
}

\begin{abstract}
This study determined the effect of institutional policy on employee performance of the academic staff of public universities in South-East, Nigeria. Survey research design was adopted. Sample of the study comprises of one thousand seven hundred and eighty Academic Staff of the ten selected Universities in South-East, Nigeria. Data was obtained from questionnaire administered on the sampled population. Data obtained was analyzed with the aid of SPSS version 20.0 that involved a regression analysis. The study findings revealed that institutional policy has positive significant effect on employee performance of the academic staff of public universities in Nigeria. Based on this, the researchers recommended that there is need for government and university authorities to formulate and implement institutional policies that are employee driven and recognizes the peculiarities of academic staff in terms of their physical and psychological needs.
\end{abstract}

Key words: Institutional Policy, Employee Performance and Academic Staff 


\section{INTRODUCTION}

The academic staff is germane to achievement of the primary objectives of tertiary institutions which hinge on advancing knowledge creation and sharing. In the context of this study, academic staff refers to university lecturers whose primary assignment is instruction, research or community service. Academic staff relevant is predicated on the premise of their principal role as the facilitators and custodian of the learning process in the tertiary institutions. This implies that the future of tertiary institutions rest in the hands of academic staff for their job satisfaction today will inevitably be reflected through innovative research and qualitative teaching in the nation future leaders. More so, academic staff through teaching and research contributes to development of individuals' and nation building. The performance of tertiary institutions is contingent on academic staff and ultimately their level of job satisfaction and job performance. Thus, understanding the behaviour of academic staff and their attitude towards work needs more attention in tertiary institutions. Tertiary institutions are described as post-secondary educational institutions that offer programs leading to award of degrees. However, the study will focus on selected tertiary institutions such as public universities. This is because public universities owned by the federal and state governments dominate the higher education system (Ogungbenle \& Edogiawerie, 2016).

Academic staff job satisfaction and performance continue to be compromised in Nigeria. This ugly situations has not only affected academic staff job satisfaction in terms of their wellbeing but has also affected their core substantive task in terms of their teaching and research performance compared to what is obtainable in developed and other developing nations. According to Khan, Nawaz, Aleem and Hamed (2012) satisfied employee is motivated to perform well in the best interest of the organization. Unfortunately, this has not been the case within Nigeria tertiary institutions particularly the public universities characterized by poor working condition, dilapidated infrastructures, poor salary structure, politicized recognition and frustrated opportunity for career advancement that has all culminated into a hostile and un-conducive working environment for academic staff to perform at their best. This upsurge adversely affects academic staff job performance which invariably reflects in the large extent of decay within public universities in Nigeria as compared to other countries. Employee performance in the context of this study refers to the task specific behaviours that academic staff exhibit as part of their job as such task specific behaviours are the core substantive tasks that delineate one job from another. It is against this backdrop, the study investigate the effect of institutional policy on employee performance of the academic staff of public universities in South-East, Nigeria.

\section{REVIEW OF RELATED LITERATURE}

Institutional policy and employee performance has dominated the research realm of psychology and organizational behaviour. This is largely because of instrumentality nature of both key concepts in influencing the overall organizational success. According to Herzberg two factor theories, employees needs for survival and growth forms their expectation of motivation and this largely determines their attitudinal and behavioural outcome. Herzberg (1959) pointed out those motivator factors to be achievement, recognition, work itself, responsibility, advancement, growth whereas hygiene factors that eliminate dissatisfactions are company policy, supervision, relationship with boss, working condition, relationship with peers and job security. According to Vroom's expectancy theory, employee would be motivated towards achieving better results because of their desire of getting higher bonuses, 
pay raise, promotions, career advancement, challenging responsibilities and favourable company policies (Parijat \& Bagga, 2014). Relying on Vroom's expectancy theory, employee will be motivated to act when there is an expectancy that their behaviour can result in achievement of desired outcomes. Thus because of the fulfillment derive from an employee being satisfied with his/her job, generates positive employee behaviour like employee performance. A number of studies has provided empirical support for the relationship between job satisfaction and employee performance. Such findings was reported by (Laosebikan, Odepidan, Adetunji \& Aderinto, 2018; Oravee, Zaym \& Kokona, 2018; Rozanna, Adam \& Majid, 2019; Madu \& Anyalebechi, 2016; Ayodele \& Olurunsola, 2012).

Organizational policy is an integral dimension of job satisfaction. Herzberg (1959) two factor theory classified organizational policy as hygiene factor in the work place that eliminates dissatisfactions among employees. Policies can be described as set of principles, rules and guidelines formulated or adopted by an organization to reach its long-term goals. According to Yaya (2019) organizational policies are necessary as they allow workers to be accountable and help in fostering a cooperative work environment among the workforce. Policies are designed to influence and determine all major decisions and actions, and all activities that take place within the boundaries set by them. Dugguh and Ayaga (2014) opined that an organization policies, administration and procedures can frustrate employee performance if the policies and procedures of an organization are ambiguous, employee disenfranchised or irrelevant. This is largely true because a work friendly and employee oriented policy is expected to address employee concern without compromising overall corporate or institutional goals which invariably is expected to influence employee performance at work. According to Herzberg two factor theory, through a well formulated and implemented organizational policies, institutions can mitigate dissatisfaction in the work place. This is because of the employee survival needs that can be provided through organizational policies. Relying on Vroom's expectancy theory, it is expected that academic staff will be motivated to perform well when they derive a valued sense of fulfillment from government and management policies as it affects them.

\section{Empirical Studies}

Khan, Nawaz, Aleem and Hamed (2012) determined the factors that influence level of job satisfaction and employee performance. The population of the study consists of doctor, paramedics, accounts and administrative staff. The sample of the study comprised of 200 doctors, nurses, administrative and accounts staff working in autonomous medical institutions in Punjab. SPSS (version 16) was used for data analysis. The study findings showed that facets of job satisfaction such as pay, promotion, job safety and security, working conditions, job autonomous, relationship with co-workers, relationship with supervisor and nature of work significantly affect the level of job satisfaction. Dizgah, Chegini and Bisokhan (2012) examined the relationship between job satisfaction (independent variable) and two dimensions of employee job performance (in-role performance and innovative performance) which both act as dependent variables in the study. Questionnaire served as a means of data collection. Whereas job satisfaction has 5 measurement items, employee performance has 13 item. In terms of data analysis, a confirmation factor analysis (CFA), Pearson moment correlations and descriptive statistics was used. The study concluded on the need to eliminate role-ambiguity in the work place in order to boost employee confidence pivotal for positive behaviour like increased employee performance. Octaviannand, Pandjaitan and Kuswanto (2017) examined the effect of job satisfaction and motivation towards employee's 
performance in XYZ shipping company located in Kuningan, South Jakarta, Indonesia. Both primary data and secondary data (questionnaires) was used in the study.70 respondents were selected with purposive sampling technique for each division works like (marketing department, customer service, logistics, documentation, cashiers, financial and port agency services) and related technologies on the shipping company XYZ. For the data analysis of the study, descriptive statistics, multiple linear regression analysis, partial test (T-test), simultaneous test (F-test) and coefficient of determination (R2) analysis was utilized. Findings pointed out that job satisfaction and employee motivation has partial and significant effect on job performance. Secondly, it revealed job satisfaction and employee motivation jointly affect the performance of employees. Ndulue and Ekechukwu (2016) ascertained the impact of job satisfaction on employees' performance in Nigerian breweries PLC Kaduna state branch. Job satisfaction was operationalized into three dimensions of nature of job, job reward and job security. Descriptive analysis, simple percentage and regression were employed. Empirical results provided support for linear relationship between job satisfaction (nature of job, job reward and job security) and employee performance (employee morale). Oravee, Zayum and Kokona (2018) determined the impact of intrinsic and extrinsic rewards aspect of job satisfaction on employee's performance on Nasarawa State Water Board, Lafia, (NSWB) Nigeria. The population of the study was 79 staff of the agency. The hypotheses was tested using chi-square test and results revealed that intrinsic (achievement and advancement) and extrinsic (promotion and pay) rewards aspect of job satisfaction significantly influence employee performance at the Nasarawa State Water Board. The study concluded that job satisfaction is germane to employee performance at NSWB as satisfied workers tend to be more concerned about given tasks, work speedily, work with free of errors and omissions, willing to accept more responsibility and perform optimally. Udo-Anyanwu and Amadi (2018) examined the relationship between reward system (extrinsic and intrinsic) and job satisfaction among library staff in tertiary institutions in Imo state. The researchers used the entire population of 101 as sample in the study. Rating scale was adopted as a means of data collection. Mean score was used for analysis of extent of workers satisfaction with reward systems (hypothesis one) whereas Pearson Product Moment Correlation (PPMC) was used to determine the relationship between the independent and dependent variables at 0.05 level of significance. Findings revealed that librarians of selected universities in Imo state were satisfied with their job. Rozanna, Adam and Majid (2019) examined the mediation effect of job satisfaction on the relationship between organizational change, organizational cultures (independent variables) and employee performance (dependent variable) of the Public Works and Spatial Planning Agency in Indonesia. The study using census technique as the number of population is small, selected all 209 staff of the Public Works and Spatial Planning Agency, Pidie District, Aceh Province of Indonesia as sample of the study. The researchers employed questionnaire as instrument for data collection. Madu and Anyalebechi (2016) examined job satisfaction and performance of Librarians in Universities in South-East, Nigeria. The study looks at the concept of job satisfaction and reviews theory on job satisfaction and its relevance to library work environment. Based on critical review of literatures, the study revealed that crucial factors in increasing job satisfaction and performance of the Librarians in Universities in South-East, Nigeria are financial rewards, fringe benefits and recognition. The study also affirmed the positive relationship between job satisfaction and employee performance. Sharma and Jyoti (2010) 'determined job satisfaction level of university teachers taking into consideration intrinsic and extrinsic factors. The researchers used simple random sampling to select 150 teachers working in university of Jammu. Multiple regression analysis through SPSS software was used to determine the extent 
of variance caused by different factors in determining the degree of job satisfaction of the university teachers. Based on the findings, it was reported that of all the dimensions of job satisfaction, the job itself accounted for $63 \%$ contribution in job satisfaction of academicians. The study findings revealed that level of occupation had a significant and positive relationship with job satisfaction whereas age and length of employment had no linear relationship with job satisfaction. Similarly, marital status and gender has no significant correlation with job satisfaction. Dauda, Maishanu and Mawoli (2013) ascertained the effect of internal service quality (ISQ) on employee job satisfaction in Abubakar Gimba Library, IBB University, Lapai, Nigeria. The population of the study comprises of all the staff of Abubakar Gimba Library, IBB University, Lapai, Nigeria. The data obtained from the respondents were summarized by means of descriptive statistics such that a lower or higher means will represent either a lower or higher internal service quality. Regression analysis was performed to ascertain the relationship between ISQ and job satisfaction. Singh and Jain (2013) examined employees' job satisfaction and its impact on their performance. Based on literature reviewed, the researchers identified factors influencing employee job satisfaction as compensation and benefit (salaries or wages, bonus, incentives), job security, working conditions, relationship with superior authority, promotion and career development, leadership style, work group and personal variables like personality, expectation, age, education and gender differences. The study also found out that job satisfaction impact on employee performance through behaviours like productivity, absenteeism, turnover, workplace deviance, organizational citizenship behaviour (OCB) and customer satisfaction. Triwahyuni and Ekowati (2017) examined the effect of employees' satisfaction on employee performance through organizational commitment. The population of this study was 106 full time employees of General Department Manager of Pt. Pindad (Persero) which consisted of administration personnel, public administration, human relation, distribution, k314 and affairs. The study utilized proportional sampling to select a sample of 86 employees. The research was quantitative based and explanatory in nature. Primary and secondary data was collected. Partial least square path modeling (PLS-PM) was used for data analysis. Findings from path coefficient analyses revealed that job satisfaction had a significant and positive direct effect on employee performance. Furthermore, results of Sobel test showed that organizational commitment does not mediate the effect of job satisfaction on employee performance. Opeke, Ikonne and Adewoyin (2019) examined job satisfaction among library personnel in public universities in South-West, Nigeria. The study adopted a census technique in selecting the entire population as the sample of the study due to small size of the population. For the purpose of data analysis, descriptive statistics such as mean and standard deviation was employed. Findings of the study showed that employee job satisfaction with their job security, relationship with co-workers, work itself and recognition was high. Dharmanegara, Sitiari and Wirayudha (2016) examined the association between job competence, work environment, and job satisfaction toward job performance. This study is explanatory research. Population of the study was workers in Small and Medium Sized Enterprises (SMEs), spa products which its industry has been registered in the Department of Industry and Trade of Denpasar with a membership in Spa Products Manufacturers Association (APPROSPA) Denpasar, Indonesia. 62 respondents were selected as the study sample. Findings fully supported four out of five hypotheses proposed in the study. The study revealed that, job competency, work environment had significant and positive effect on job satisfaction; but job competency had significant but negative effect on job performance. Prasanga and Gamage (2012) determined job satisfaction and job performance of the sailors in Rapid Action Boat Squadron of Sri Lanka Navy. Questionnaire was used as a means of data collection. Using 
Pearson product moment correlation analysis was performed to test the relationship between independent variable (job satisfaction) and dependent variable (job performance). The study findings showed that there was a significant and positive relationship between job satisfaction and job performance of the Sailors in Rapid Action Boat Squadron of Sri Lanka Navy.

However, few Nigeria studies that investigated job satisfaction on employees' performance in tertiary institution particularly the universities appeared to have majorly focused on nonacademic staff. with scant knowledge on lecturers who are also a major player in tertiary institutions and principle actor in delivery of tertiary education. Other similar studies in educational context were conducted in secondary schools with teachers as respondent. Some of such studies were reported by (Usikalu, Ogunleye \& Effiong, 2015; Gana, Bukar \& Kadai, 2011).

In addition, most of the Nigeria studies reviewed in the area of job satisfaction and employee performance appears to have majorly focused on understanding the motivational factors that contributes to job satisfaction, thereby leaving much to be desired in terms of understanding how job satisfaction affects employee performance relevant for organizational success. Meanwhile, Nigeria studies with regards to job satisfaction appeared to have focused on behavioural outcome outside employee performance as was reported in studies on job satisfaction and commitment (Oyewobi, Suleiman \& Jamil, 2012); job satisfaction on organizational commitment (Akeke, Akeke \& Awolusi, 2015); compensation management and employee job satisfaction (Adeoye \& Fields, 2014); job satisfaction on motivation (Ololube, 2006); leadership style and job satisfaction (Jerome, 2018). Based on extensive review of literature, other Nigeria studies that made effort to link job satisfaction with employee performance was conducted in manufacturing firm which characteristics differs from academic settings. It is in view of the existing research gap identified in the literature that the present study aims to investigate institutional policy and employee performance in selected tertiary institutions in South-East, Nigeria.

\section{METHODOLOGY}

This study adopted survey research design. According to Nworgu (2004), this design involves the gathering of data through questions and interviews from few people or items considered to be representative of the entire group. This design was selected for this study because the study seeks to sample the opinion of respondents and draw inferences based on their views.

The population of the study consists of ten selected Public Universities in Nigeria. As a result, purposive sampling technique was applied (Non-random sample) to select1780 Academic Staff of these Universities.

\section{Method of Data Analysis}

To test the significant effect and the relationship between the dependent variable and independent variables, Regression analysis and Pearson Product Moment Correlation Coefficient were used to test the five formulated hypotheses with the aid of SPSS version 20 . 0 . at $5 \%$ level of significance. 


\section{Decision Rule:}

The decision for the hypotheses is to accept the alternative hypotheses if the p-value of the test statistic is less or equal to the alpha at $5 \%$ and to reject the alternative hypotheses if the pvalue of the test statistic is greater than alpha at $5 \%$ significance level.

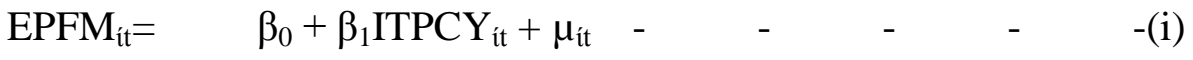

Where:

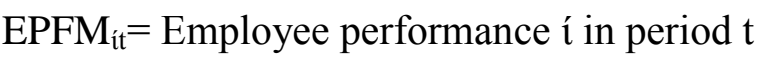

ITPCY $_{\mathfrak{i t}}=$ Institutional policy $i ́$ in period $\mathrm{t}$

$\beta_{0}=$ Constant term (intercept)

$\beta_{\mathrm{it}}=$ Coefficients to be estimated for firm $\mathrm{i}$ in period $\mathrm{t}$

$\mu_{\mathrm{it}}=$ Error term/Stochastic term for firm $\mathrm{i}$ in period $\mathrm{t}$

\section{Decision Rule}

Reject $\mathrm{H}_{\mathrm{o}}$ if the P-value of the test is less than $\alpha$-value (level of significance) at 5\%, otherwise accept $\mathrm{H}_{\mathrm{I}}$

\section{ANALYSIS OF DATA}

\section{Hypothesis One}

$\mathrm{H}_{01}$ : Institutional policy has no positive significant effect on employee performance of the academic staff of public universities in Nigeria.

Table 1: Model Summary

\begin{tabular}{|l|r|r|r|c|}
\hline Model & \multicolumn{1}{|c|}{$\mathrm{R}$} & R Square & Adjusted R Square & $\begin{array}{l}\text { Std. Error of the } \\
\text { Estimate }\end{array}$ \\
\hline 1 & $1.000^{\mathrm{a}}$ & .999 & .999 & 151.68283 \\
\hline
\end{tabular}

a. Predictors: (Constant), ITPCY

Table 1 shows an adjusted $\mathrm{R}^{2}$ value of .999 . The adjusted $\mathrm{R}^{2}$, which represents the coefficient of determinations imply that $100 \%$ of the total variation in the dependent variable (job performance) is explained by the explanatory variable (institutional policy). The adjusted $\mathrm{R}^{2}$ of $100 \%$ did not constitute any problem to the study model and further suggests that the explanatory variable is properly selected and used. The value of adjusted $\mathrm{R}^{2}$ of $100 \%$ also shows that no other variation in the dependent variable is explained by other factors; hence the entire variable was captured in the study model. 
Table 2: ANOVA ${ }^{\mathrm{a}}$

\begin{tabular}{|c|c|c|c|c|c|c|}
\hline \multicolumn{2}{|c|}{ Model } & & $\mathrm{df}$ & Mean Square & $\mathrm{F}$ & Sig. \\
\hline \multirow{3}{*}{1} & Regression & 122148545.759 & 1 & 122148545.759 & 5309.034 & $.000^{\mathrm{b}}$ \\
\hline & Residual & 69023.041 & 3 & 23007.680 & & \\
\hline & Total & 122217568.800 & 4 & & & \\
\hline
\end{tabular}

a. Dependent Variable: EPFM

b. Predictors: (Constant), ITPCY

Table 3: Coefficients ${ }^{\mathrm{a}}$

\begin{tabular}{|c|c|c|c|c|c|}
\hline \multirow[t]{2}{*}{ Model } & \multicolumn{2}{|c|}{ Unstandardized Coefficients } & \multirow{2}{*}{$\begin{array}{c}\text { Standardized } \\
\text { Coefficients } \\
\text { Beta } \\
\end{array}$} & \multirow[t]{2}{*}{$\mathrm{t}$} & \multirow[t]{2}{*}{ Sig. } \\
\hline & $\mathrm{B}$ & Std. Error & & & \\
\hline (Constant) & 152.438 & 97.752 & & 1.559 & .217 \\
\hline ITPCY & 3.191 & .044 & 1.000 & 72.863 & .000 \\
\hline
\end{tabular}

a. Dependent Variable: EPFM

In table 2 , it reveals that the p-value is 0.000 showing that the hypothesis is statistically significant at level of significance (5\%); hence p-value of the test statistic is less than alpha value. The result also showed a positive effect between the institutional policy and job performance of the academic staff. In table 3, the regressed coefficient correlation result shows that an evaluation of the salary of the explanatory variable (Beta Column) has about $100 \%$ positive effect on job performance.

However, the data was subjected to further analysis to determine the level of significant that exists between the two variables.

Table 4: Correlations

\begin{tabular}{|rl|r|r|}
\hline & & EPFM & \multicolumn{1}{|c|}{ ITPCY } \\
\hline \multirow{2}{*}{ EPFM } & Pearson Correlation & 1 & $1.000^{* *}$ \\
& Sig. (2-tailed) & & .000 \\
& $\mathrm{~N}$ & 5 & 5 \\
& Pearson Correlation & $1.000^{* *}$ & 1 \\
ITPCY & Sig. (2-tailed) & .000 & \\
& $\mathrm{~N}$ & 5 & 5 \\
\hline
\end{tabular}

**. Correlation is significant at the 0.01 level (2-tailed).

Indeed, from the above figure, correlation coefficient of 1.000 a positive correlation between institutional policy and job performance. To get an idea of how much variance the two variables share, the coefficient of determination $(R)$ is calculated. $R$ is $1.000 \times 1.000=1.000$. It implies that institutional policy help to explain $100 \%$ of the variance in job performance in the university. From the above result, the study discovers that the confidence level between institutional policy and job performance is high, and the correlation coefficient is significant 
at 0.01 levels. Therefore, the institutional policy has positive significant effect on the job performance of the academic staff of public universities in Nigeria.

\section{Decision:}

Since p-value of the test statistic is less or equal to alpha, we therefore, reject null hypothesis and uphold alternative hypothesis which state that institutional policy has positive significant effect on employee performance of the academic staff of public universities in Nigeria.

\section{CONCLUSION AND RECOMMENDATION}

Based on findings of the study, it was found out that the relationship between institutional policy and employee performance is statistically significant and with a positive effect. These findings corroborate with the findings of Ayodele and Olurunsola (2012) whom study revealed that there is a significant and positive relationship between policy and job performance. According to Yaya (2019) institutional policies is essential element in management as they facilitate enabling work environment where employees derive a sense of accountability and feel motivated to achieve organizational goals along with their career development. Policies are designed to influence and determine all major decisions and actions, and all activities that take place within the boundaries set by them. This is in line with Dugguh and Ayaga (2014) whom opined that an organization policies, administration and procedures can frustrate employee performance if the policies and procedures of an organization are ambiguous, employee disenfranchised or irrelevant. According to Herzberg two factor theory, through a well formulated and implemented organizational policies, institutions can mitigate dissatisfaction in the work place. This is because of the academic staff survival needs that can be addressed through employee driven institutional policies. Relying on Vroom's expectancy theory, it is expected that academic staff will be motivated to perform well when they derive a valued sense of fulfillment from government and management policies as it affects them. Therefore, a work friendly and employee (academic staff) driven institutional policy is expected to address employee (academic staff) concern without compromising overall institutional goals which invariably is expected to influence employee performance at work.

Based on this, the researchers recommended that there is need for government and university authorities to formulate and implement institutional policies that are employee driven and recognizes the peculiarities of academic staff in terms of their physical and psychological needs. This includes amongst other giving academic staff authority to seamlessly undertake core academic and administrative activities within public universities devoid of government interference. The researcher is of the view that such considerations will protect the autonomy and interest of academic staff which in returns will account for a greater job satisfaction and the consequential outcome of an enhanced academic staff performance. 


\section{REFERENCES}

Adeoye, A. O., \& Fields, Z. (2014). Compensation Management and Employee Job Satisfaction: A Case of Nigeria. Journal of Social Science, 41(3), 345-352.

Akeke, N. I., Akeke, A. R., \& Awolusi, O. D. (2015). The Effect of Job Satisfaction on Organizational Commitment among Non-Academic Staff of Tertiary Institutions in Ekiti State. International Journal of Interdisciplinary Research Method, 2(1), 25-39.

Ayodele, J. B., \& Olorunsola, E. O. (2012). The Relationship between Job Satisfaction and Performance of Administrative Staff in South West Nigeria Universities. Journal of Social Science, 30(3), 313-316.

Dauda, A., Maishanu, M. M., \& Mawoli, M. A. (2013). Effect of Internal Service Quality on Employee Job Satisfaction: Evidence from Abubakar Gimba Library, IBB University, Lapai-Nigeria. American International Journal of Contemporary Research, 3(6), 8896.

Dharmanegara, I. B. A., Sitiari, N. W., \& Wirayudha, I. G. (2016). Job Competency and Work Environment: The Effect on Job Satisfaction and Job Performance among SMEs Worker. IOSR Journal of Business and Management, 18(1), 19-26.

Dizgah, M. R., Chegini, M. G., \& Bisokhan, R. (2012). Relationship between Job Satisfaction and Employee Job Performance in Guilan Public Sector. Journal of Basic and Applied Scientific Research, 2(2), 1735-1741.

Dugguh, S. I., \& Ayaga, D. (2014). Job Satisfaction Theories: Traceability to Employee Performance in Organizations. IOSR Journal of Business and Management, 16(5), $11-18$.

Gana, A. B., Bukar, A. G., \& Kadai, Y. M. (2011). An Assessment of Teacher's Job Satisfaction and Job Performance in Three Selected Secondary Schools of Borno State, Nigeria. Continental Journal of Education Research, 4(1), 28-34.

Herzberg, F. (1959). The motivation to work. New York: John Wiley.

Jerome, I. (2018). An Investigation on the Nexus between Leadership Style and Job Satisfaction of Library Staff in Private University Libraries South-West, Nigeria. Library Philosophy \& Practice, 1(1), 1-32.

Khan, A. H., Nawaz, M. ., Aleem, M., \& Hamed, W. (2012). Impact of Job Satisfaction on Employee Performance: An Empirical Study of Autonomous Medical Institutions of Pakistan. African Journal of Business Management, 6(7), 2697-2705.

Laosebikan, J. O., Odepidan, M. A., Adetunji, A. V., \& Aderinto, C. O. (2018). Impact of Job Satisfaction on Employees Performance in Selected Microfinance Banks in Osogbo Metropolis, Osun State, Nigeria. International Journal of Social Sciences and Management Research, 4(8), 22-46.

Madu, C. C., \& Anyalebechi, L. I. (2016). Job Satisfaction and Performance of Librarians in Universities in South East Nigeria. Journal of Policy and Development Studies, 10(4), 92-101.

Ndulue, T. I., \& Ekechukwu, H. C. (2016). Impact of Job Satisfaction on Employees Performance: A Study of Nigerian Breweries Plc. Kaduna State Branch, Nigeria. Kuwait Chapter of Arabian Journal of Business and Management Review, 5(11), 13 23.

Octaviannand, R., Pandjaitan, N. K., \& Kuswanto, S. (2017). Effects of Job Satisfaction and Motivation towards Employee's Performance In XYZ Shipping Company. Journal of Education and Practice, 8(8), 72-79. 
Ogungbenle, S. K., \& Edogiawerie, M. N. (2016). Budgetary Allocation and Development in Nigeria Tertiary Institutions. Igbinedion University Journal of Accounting, 2(1), 377407.

Ololube, N. P. (2006). Teachers Job Satisfaction and Motivation for School Effectiveness: An Assessment. Essays in Education, 18(1), 1-19.

Opeke, R., Ikonne, C. N., \& Adewoyin, O. O. (2019). Job Satisfaction among Library Personnel in Public Universities in South-West Nigeria. Journal of Information and Knowledge Management, 10(2), 124-138.

Oravee, A., Zayum, S., \& Kokona, B. (2018). Job Satisfaction and Employee Performance in Nasarawa State Water Board, Lafia, Nigeria. Cimexus, 13(2), 59-70.

Oyewobi, L. O., Suleiman, B., \& Jamil, A. M. (2012). Job Satisfaction and Job Commitment: A Study of Quantity Surveyors in Nigeria Public Service. International Journal of Business and Management, 7(5), 179-192.

Parijat, P., \& Bagga, S. (2014). Victor Vroom's Theory of Motivation: An Evaluation. International

Prasanga, A. P. A., \& Gamage, A. S. (2012). Job Satisfaction and Job Performance of the Sailors in Rapid Action Boat Squadron of Sri Lanka Navy. Sri Lankan Journal of Human Resource Management, 3(1), 49-57.

Rozanna, N., Adam, M., \& Majid, M. S. A. (2019). Does Job Satisfaction Mediate the Effect of Organizational Culture on Employee Performance of The Public Works and Spatial Planning Agency? IOSR Journal of Business and Management, 21(1), 45-51.

Sharma, R. D., \& Jyoti, J. (2010). Job Satisfaction of University Teachers: An Empirical Study. Journal of Science Research, 9(2), 51-80.

Singh, J. K., \& Jain, M. (2013). A Study of Employees' Job Satisfaction and Its Impact on their Performance. Journal of Indian Research, 1(4), 105-111.

Triwahyuni, R., \& Ekowati, V. M. (2017). The Effect of Employees Satisfaction on Employee Performance through Organizational Commitment. Management and Economics Journal, 1(1), 1-12.

Udo-Anyanwu, A. J., \& Amadi, C. C. (2018). Reward Systems and Job Satisfaction of Librarians in Academic Libraries in Imo State, Nigeria. Journal of Applied Information Science and Technology, 11(2), 149-158.

Usikalu, O., Ogunleye, A., \& Effiong, J. (2015). Organizational Trust, Job Satisfaction and Job Performance among Teachers in Ekiti State, Nigeria. British Open Journal of Psychology, 1(1), 1-10.

Yaya, J. A. (2019). Job Satisfaction among Librarians in Nigerian Public Universities. Journal of Library Services and Technologies, 1(1), 73-92. 